\title{
ON THE FUNCTIONS OF ANTONOMASIA IN POLITICAL DISCOURSE
}

\author{
Ofelya Poghosyan* \\ Varduhi Ghumashyan** \\ Yerevan State University
}

Political discourse as a variety of persuasive, impressive and effective speech is one of the ways of constructing optimal speech interchange varying from political negotiations to orations and appeals (including the ones in mass media). It is a well-known fact that the audience of politicians is very large, and their aim is to influence the audience by making accept their viewpoints or at least share their approaches to most urgent problems. In this respect the issue of a proper utilization of language means in political discourse gains particular significance. In this paper, we emphasize the role of antonomasia. Specifically, we argue that antonomasia is often found in political speeches to achieve a particular effect by supporting the politician's intention to send the desired message, orally or in written form, to his audience. Thus, in the frames of the present article, by the application of the methods of observation, description and the elements of discourse analysis, we will study the range of functions performed by antonomasia in political discourse.

Keywords: political discourse, extra-linguistic means, antonomasia, stylistic devices, persuasive function, manipulative function, cognitive function.

\section{Introduction}

The aim of the present article is to provide an overview of the main characteristics of antonomasia and reveal the functions of antonomasia as manifested in political discourse. The analysis of stylistic devices in general, and that of antonomasia in particular, as well as the study of their functions are essential to any kind of discourse. As far as the political discourse (van

\footnotetext{
*ofelyapoghosyan54@mail.ru

**vvghumashyan@mail.ru
}

This work is licensed under a Creative Commons Attribution-NonCommercial 4.0 International License.
Received: 20.01.2021

Revised: 21.04.2021

Accepted: 20.05.2021

(C) The Author(s) 2021 
Dijk, 1985; Shapiro, 1981) is concerned, it is actively used in the social, political and cultural spheres of the global community for the purpose of exchanging ideas on a range of topical issues.

As a substyle or a genre of publicistic functional style political discourse is based on an ontological juxtaposition of fact and fiction which is fundamental for the choice of language units and stylistic devices (Muradian, 2003). Antonomasia in publicistic style in general and in political discourse, in particular, is based on different cases of transposition of logical and nominative meanings. The interplay between the logical and nominal meanings of a word is often intentionally used to express the speaker's emotions and attitudes to the object of discussion (in the case of antonomasia it is usually a human being). It is also viewed as a shift from one nominal category to another or a controversy between the traditional and situational reference purely on the level of style (Galperin, 1981).

Antonomasia conveys a wide spectrum of qualitative characteristics which can be understood in different subjective ways; this in its turn gives an opportunity to the speaker to play and manipulate with the words as he or she likes by enriching the words with new meanings which usually cannot be perceived by ordinary people unfamiliar with the topic of the speech and with no idea of the politician's intentions and aims (Burnside, 2004; Jackson\&Amvela, 2000). It is this quality that has brought our attention to the mentioned device and has urged us to discuss in what ways antonomasia may work in the hands of a political speaker.

The study of the definition of the term antonomasia in the works of Galperin (1981), Crystal \& Derek(1971), Kukharenko \& Soshalskaya (1964) displays a variety of interpretations, which however, do not vary in their core content. In most general terms, antonomasia is defined as a device in which one person's name is exchanged or substituted by another person's name or by an epithet (Galperin, 1981). Antonomasia is based on the interaction of the logical and nominative meanings of the same word. One of the interacting meanings is independent of the context, while the other is born within the context. Depending on the character of the contextual meaning, a distinction between two types of antonomasia can be drawn:

a) A name change based on the interaction between the nominative and contextual logical meanings; 
b) If the interacting meaning of the word is independent of the context, it is its nominative meaning that is dealt with, and if it arises in the context, it is the logical meaning of the word that comes into being (Kukharenko \& Soshalskaya, 1964).

With the account of this distinction, in the following part of the paper we will demonstrate the range of language means through which antonomasia functionally gets manifested in political discourse.

\section{Key functions of antonomasia}

Antonomasia comprises cases in which a proper noun is used for a common noun, for example, a title is used instead of the words king, ambassador, pope or their names. The language unit used with a new meaning is written in capitalized letters, and this proper noun stands for a quality which becomes almost inseparable from the named character. When a title is used instead of a name, we deal with an antonomastic comparison (Kukharenko, 1964). A title or a formal description such as Your Highness is used for a king or his proper name, or Your Excellency is used for an ambassador or his proper name, or the official address for a pope is Your Holiness. These are examples of antonomasia, in other words, antonomastic comparison. This type of antonomasia performs an informative function; the audience can immediately understand that the speaker's words refer to a person who has a high position, title or rank in the society.

We may also observe cases when antonomasia performs a function of vocabulary enrichment. For instance, instead of saying 'a political leader with tyrannical, cruel and arbitrary exercise of power' a politician may employ the word 'dictator' for a person who dictates his own will to other people, or instead of the noun racist the word furher borrowed from German came to be used in English political discourse not only as a common noun, but also as a substitution for a proper name.

The observation of the phenomenon of antonomastic comparison brings us to the conclusion that practically any proper noun can be used as a common name. There are situations when a proper name stands for some general idea, either to refer to somebody or something with associated characteristics, or to designate a member of a group or class, for example, a traitor among politicians is called Arnold. 
On the basis of the analysis of antonomasia in political discourse it can be assumed that the usage of an epithet instead of a proper name may be considered a case of antonomasia as well, for example, His Majesty for king, or racist/fuhrer for Hitler. Conversely, a proper name can be used as an appellative (common noun), for instance, a wise man is called Solomon, an eminent orator - Cicero; a betrayer is referred to as Judas or a political leader who possesses absolute power - a Dictator. In political discourse, this type of usage of proper names often takes place for manipulative purposes. Hence the manipulative function of antonomasia can be highlighted.

It goes without saying that when someone is referred to as Judas ("Judas," n.d.), we immediately realize that it refers to betrayal. Although we do not turn to history in these situations and use antonomasia automatically and subconsciously, we do understand that this phenomenon is directly linked to our background knowledge. Hence, it can be concluded that antonomasia performs an intellective function as well.

On the basis of the analysis of the cases of antonomasia in political discourse we observe that the use of antonomasia concretizes political notions, by underlining or highlighting the characteristic features of the people mentioned, or the events going on; the awareness of the source helps understand the intentions of the speaker adequately (consciously referring to the information about a specific person or phenomenon).

In fact, in political speeches and political texts in general, we can find examples of an exact and definite estimation of the existing realities with the help of stylistic devices. The comparison with antonomastic characters actually performs a cognitive function, revealing the speaker's attitude towards the person or the object referred to. In all these instances it is quite obvious that the speaker is willing to violate the stern political speech (Beard, 2000) by playing with the words, as well as to show his or her awareness and erudition by presenting the given political question in a playful, jolly manner. For example:

I say this to our American friends. Mr. Facing-Both-Ways does not get very far in this world.

I suspect that the Noes and Don't Knows would far outnumber the Yesses. ("Interaction of logical", 2018) 
It is important to mention that listeners or readers of political speeches should have enough background knowledge of the question under discussion, otherwise they will not be able to perceive the politician's message, and consequently the latter will succeed in manipulating the audience.

\section{On the ornamental function of antonomasia}

Figures of speech are used to add emphasis to what we say or write (Gasparyan, 2000; Gasparyan \& Matevosyan, 2008). We assume that even political speech can obtain vivid expressiveness when it is ornamented with different stylistic devices. Hence, the use of antonomasia in some situations performs not only an informative but also an ornamental function, for example: The Iron Butterfly for the former Philippine first lady Imelda Marcos; or Iron Rita for the former Dutch immigrant, Minister Rita Verdonk; Titanium Lady for the former State Secretary of the United States Madeleine Albright, Iron Lady for Margaret Thatcher.

The ornamental function of antonomasia can be observed in the abstract from Ronald Reagan's speech on "The Space Shuttle 'Challenger' Tragedy Address" delivered in January 28, 1986:

We mourn the loss as a nation together. For the families of the seven, we cannot bear, as you do, the full impact of this tragedy. But we feel the loss, and we are thinking about you so very much. Our loved doves (the members of shuttle Christa McAuliffe, Dick Scobee, Mike Smith, Ron McNair, Judy Resnik, Ellisson Onizuka and Gregory Jarvis) where daring and brave and they had that special grace, that special spirit that says, "Give me a challenge, and I'll meet it with joy. ("Address to the Nation", 1986).

The word combination 'our loved doves' stands for the names of the members of the Space Shuttle Challenge to express the incredibly strong sense of pity and sorrow, and in this context we may conclude on the ornamental function of antonomasia. 


\section{On the declarative and informative, persuasive and manipulative functions of antonomasia}

So far it has been revealed that antonomasia performs several functions, including declarative and informative functions, as well a function of persuasion (or a persuasive function), which is closely interrelated with the manipulative function.

We consider that if Saddam Hussein had not started war against Kuwait the US President George H. W. Bush would not have named him 'the dictator' during one of his famous speeches in 1991. Here we have a vivid example of antonomasia: the speech of US President George W. Bush at the time of decision to go to war with Iraq in 1991 is as follows:

Just two hours ago, Allied Air Forces began an attack on military targets in Iraq and Kuwait. These attacks continue as I speak. Ground forces are not engaged. This conflict started Aug. 2, when the dictator (Saddam Hussein) of Iraq invaded a small and helpless neighbor Kuwait; a member of the Arab League and a member of the United Nations, was crushed, its people brutalized. Five months ago, Saddam Hussein started this cruel war against Kuwait; tonight, the battle has joined. ("George $\mathrm{H}$. W. Bush Speech", 1986)

Bush begins by emphasizing the fact that the attack has already begun and that it is still going on. His speech is strikingly declarative and informative. He implies that there was no other choice but to begin the war and that America had no desire to play a role of an aggressor. Indeed, Bush stresses the idea of the 'dictator of Iraq', Saddam Hussein, having 'invaded a small and helpless neighbor'. The extract with the usage of the word dictator persuades the reader to agree with the speaker, consequently, performing a persuasive function.

Another interesting example of the persuasive function of antonomasia is found in the text on Barack Obama's electoral campaign.

African-Americans arrived at the polls today in large numbers to support Barrack Obama - but on Election 
Day 2012, it's less about the historic jubilation of 2008 than ensuring that job growth, health care and education reform keep on track. .... "Barack Obama is not a Martin Luther King Jr. - people recognize that, "argued the Rev. Calvin O. Butts III, who has led the historic Abyssinian Church in Harlem for 40 years. "There is a greater sense of reality. He is a man not a savior”. (Donaldson, 2012)

By presenting specific details connected with the given phenomenon, the author evokes a concrete and life-like image and expresses certain feelings of his own, plays with words intentionally and, in fact, persuades the listeners or readers to believe him. Antonomasia enables listeners or readers to grasp the main contextual essence by evoking great interest towards the text at the same time performing motivational function as well, besides its persuasive function. Political speeches are often made in the wake of political scandals where the motivation of the speaker is to persuade the listeners.

Thus, it can be stated that some of the functions of antonomasia in one and the same context are interconnected and interdependent.

\section{Conclusion}

Language is the principal tool of politicians to achieve their goals in the course of their communicative discourse with the audience either in written or in oral form. Language is a powerful and emotive stimulant, dangerous in the hands of a skilled orator. Thus, antonomasia, as a rhetoric device, is frequently used by politicians to impose their views on their listeners or readers and send their messages either directly or indirectly to the addressees.

Politics is viewed as a struggle for power, between those who seek to assert their power and those who seek to resist it. Accordingly, politicians constantly aim at making their speeches irresistible, which often becomes possible due to the utilization of various lexical means and stylistic devices. The aim of a particular rhetoric device (for example, antonomasia) in any kind of discourse in general, and in political discourse in particular, is to carry out a certain function. Moreover, depending on the politician's 
intention in a particular context, the usage of antonomasia often aims at realizing more than one function in one and the same extract of the discourse, in other words, different functions may be interdependent, interconnected and intertwined within the same frame of the subject.

Thus, the role of antonomasia in political discourse is significant and deserves attention due to the following functions it may perform:

1. Informative and Declarative;

2. Intellective;

3. Motivational;

4. Ornamental;

5. Cognitive ;

6. Manipulative;

7. Persuasive ;

8. The Function of Vocabulary Enrichment.

\section{References}

Beard, A. (2000). The language of politics. London, England: Routledge. Burnside, J. (2004). Word watching. Washington, USA: Thunder's Mouth Press.

Cook, G. (1989). Discourse. Oxford, England: London Print.

Crystal, D. \& Derek, D. (1971). Investigating English style. New York, USA: Longman.

Dijk, T. (1985). Handbook of discourse analysis. Discourse and dialogue. London, England: Academic Press.

Galperin, I. (1981). Lexical and lexico-phraseological expressive means. Moscow, URSS: Nauka.

Gasparyan, S. (2000). Figura sravneniya $v$ funkcionalnom osveschenii. [Simile from the functional-communicative perspective]. Yerevan, Armenia: Lusakn.

Gasparyan, S., \& Matevosyan, A. (2008). English style in action. Yerevan, Armenia: Lusakn.

Jackson, H., \& Amvela, E. (2000). Words, meaning and vocabulary: an introduction to modern English Lexicology. London, England: Continuum. 
Kukharenko, V., \& Soshalskaya, Y. (1964). Konspekt lektsiy po stilistike angliyskogo yazyka. [Notes of the lectures on Stylistics of the English language]. Odessa, USSR: Odesskiy Gosudarstvenniy Universitet.

Muradian, G. (2003). Hraparakakhosakan ardzaky vorpes gortsarakan votcheri hakadramiasnutyun [The juxtaposition of fact and fiction in public discourse]. Synopsis of $\mathrm{PhD}$ Dissertation, Yerevan State University, Yerevan, Armenia.

Shapiro, M. (1981). A comparative and political analysis. Chicago, USA: University of Chicago Press.

\section{Sources of Data}

Address to the nation by President Ronald W. Reagan. (1986, January 28). Retrieved from https://history.nasa.gov/reagan12886.html

Donaldson S.J. (2012, November 6). African-American vote: Obama is a 'Man Not a Savior'. Retrieved from https://abcnews.go.com/amp/Politics/OTUS/african-americans-voting-jubilance\%20loyalty-election2012/story?id=17655594

George H. W. Bush speech, attack on Iraq 1991 (Excerpts). (2018, March

17). Retrieved from GeorgeHWBushAttackonIraq1991Excerpts.pdf

Interaction of logical and nominal meanings Antonomasia. (2018, December 2). Retrieved from https://studfile.net/preview/7322038/page:29/

Judas. (n.d.). In Your Dictionary. Retrieved from https://www.yourdictionary.com/judas

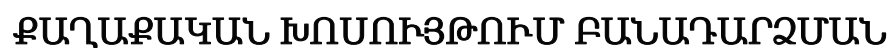

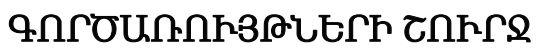

\section{O\$teju Tnпnujuiq

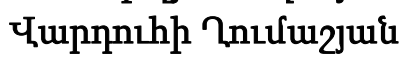

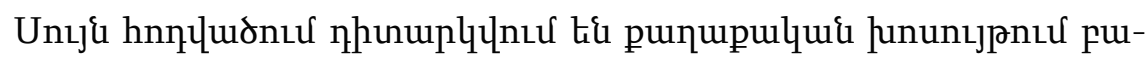

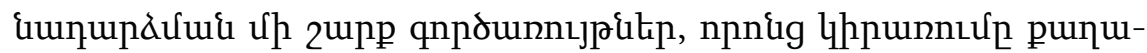

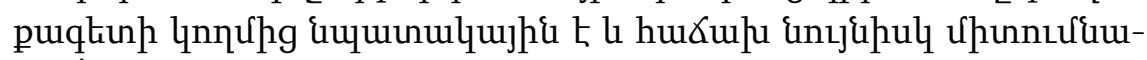

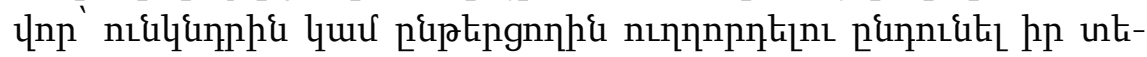




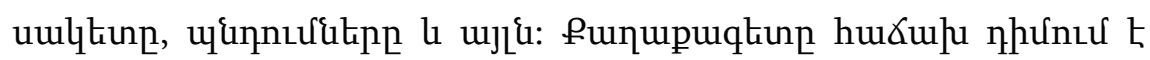

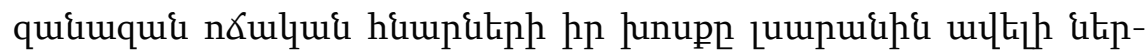

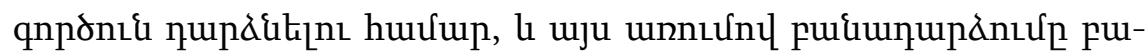

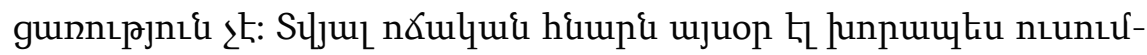

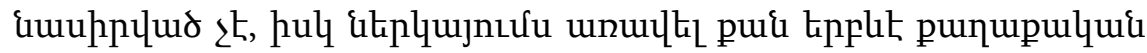

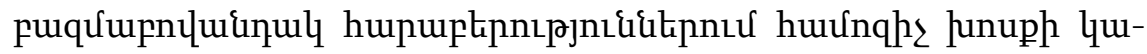

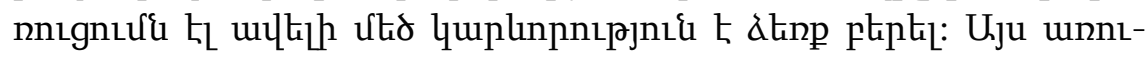

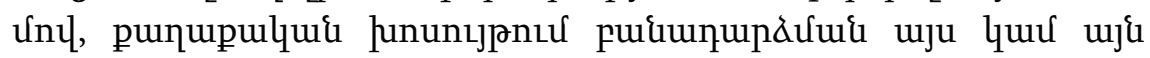

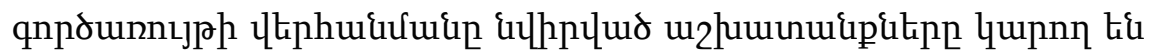

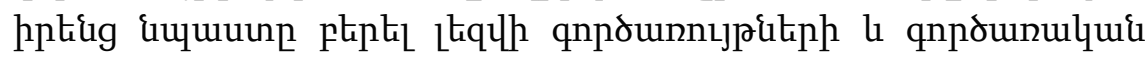

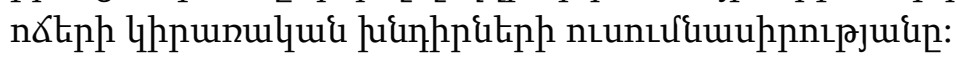

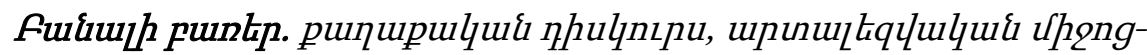

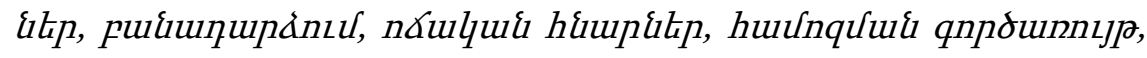

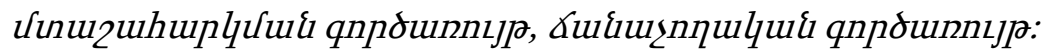

